\section{Emerging patterns in overweight and obesity in Ecuador}

\author{
Adam Bernstein
}

Suggested citation: Bernstein A. Emerging patterns in overweight and obesity in Ecuador. Rev Panam Salud Publica. 2008;24(1):71-4.

Key words: overweight, obesity, Ecuador.

Harvard School of Public Health, Department of Nutrition, Boston, Massachusetts, United States of America. Send correspondence and requests for reprints to: Harvard School of Public Health, Department of Nutrition, 665 Huntington Avenue, Boston, Massachusetts 02115, United States of America; e-mail: abernste@hsph.harvard.edu.
Ecuador, like many countries in the Americas, has seen a rise in the prevalence of overweight and obesity. Yet data in Ecuador on these chronic nutritional disorders are scarce. A review of the data that have been reported, however, suggests that important patterns are emerging.

Rapid economic and demographic changes in developing countries such as Ecuador may facilitate the replacement of low-calorie diets from predominantly plant-based sources with high-calorie diets rich in fat, sugar, and refined grains from predominantly animal-based sources $(1,2)$. International policies that increase foreign trade and extend the reach of transnational food corporations enable this nutrition transition by bringing new, and more, food products into developing markets $(1,3)$. Shifts in population growth, age structure, and income distribution, as well as increasing urbanization, also enable this transition by creating large, centralized consumer bases (1). One of the recognized untoward effects of this transition, concomitant with decreases in physical activity, is an increase in a developing country's risk for epidemic overweight and obesity (1-4).

There are data to suggest that such a nutrition transition is under way in Ecuador. In 2003, for example, using data collected by its own survey teams, the World Health Organization (WHO) estimated that nearly $60 \%$ of the Ecuadorian population ate fewer than three servings of fruit and vegetables per day and nearly $90 \%$ ate fewer than five servings (5). The Food and Agriculture Organization estimated that roughly $65 \%$ of the country's calories came from grains, fats, oils, sugars, and sweets (6). Between 1989 and 2003, the average citizen's total caloric intake rose from 2490 to 2710 kilocalories and included 100 grams of fat per day (6). Although data on the particular foods that compose this new diet are not yet available, Manuel Baldeon of the Universidad San Francisco de Quito (personal communication, 16 January 2007) reports that Western-style fast food like McDonald's and KFC does not play a large part, as it is infrequently consumed and often regarded as a treat. David Chiriboga, also of the Universidad San Francisco de Quito (personal communication, 2 January 2007), reports that commonly eaten foods in cities include white bread, white rice, egg-less pasta, soda, fruit juice, fried hot dogs, fried potatoes, fried pork, and fried plantains. These inexpensive, high-calorie foods are similar to those found in predominance in 
other cities worldwide (1), as they are high in fat, animal products, sugar, and refined grains. Moreover, this urban diet has been linked to overweight and obesity in other developing countries (7). Of note, the inclusion of many fried foods bespeaks the increasing availability of inexpensive, high-calorie cooking oil on the global market (8).

Concomitant with the nutrition transition, WHO reported in 2005, also using data collected by its own survey teams, that $40 \%$ of men and $50 \%$ of women were overweight (body mass index greater than 25 ) and $6 \%$ of men and $16 \%$ of women were obese (body mass index greater than 30) (9). It is important to note that Ecuador's national census bureau does not yet report statistics on overweight and obesity (10). Although studies in other developing countries report higher rates of overweight and obesity among adults of low socioeconomic status (SES) than among adults of high SES $(11,12)$, in Ecuador, there is scant evidence on this relationship, as studies to date have chiefly focused on the relation between SES and undernutrition (13-15). Ecuadorian girls and boys show overweight and obesity patterns similar to those of adults (16-19), which is similar to patterns observed in most $(1,12$, 20, 21), but not all (22), Latin American countries. The higher rates among Ecuadorian women compared with men, and especially among women residing in cities, have been attributed to cultural traditions, exposure to extensive food advertising, greater physical inactivity, social marginalization, and lack of financial independence $(11,12)$. Increased risk among children has been linked with higher SES, urban residence, and a higher level of maternal education (12). It is worth noting that the small body frame and short limbs of indigenous Ecuadorians may not allow the body mass index (calculated as weight in kilograms divided by height in meters squared) to accurately estimate excess body fat: a sitting-height-to-standing-height ratio may be more accurate (23).

Studies evaluating chronic disease associated with overweight and obesity have shown that death from heart disease remained stable among Ecuadorian women between 1970 and 2000 at $21 \%$ to $22 \%$ of all deaths, whereas for men it climbed from $32 \%$ to $36 \%$ (24). Trends in obesity-related cancer mortality, such as postmenopausal breast and endometrial cancer, are difficult to estimate (25). Death from diabetes rose from $8 \%$ of all deaths to $18 \%$ for men between 1990 and 2000; for women during the same time period, it rose from $11 \%$ to $22 \%$ (26). Metabolic syndrome (a condition associated with excess weight and increased risk for cardiovascular disease and defined by the presence of any three of the following: hypertension, hypertriglycidemia, central obesity, low level of high density lipoprotein choles- terol, and elevated fasting glucose) among postmenopausal women in the city of Guayaquil was recently estimated at $41 \%$ (27).

The epidemiologic evidence thus suggests an association between dietary change, excess weight, and metabolic disease. Efforts to prevent or treat these conditions, however, have begun only at a local level: Quito, for example, has created the cyclopaseo, a pedestrian mall, to increase community physical activity. There are models, though, for national initiatives: neighbors Chile and Brazil have large intervention programs that may be considered for adoption $(20,28)$, WHO detailed a way to reduce the burden of disease (29), the Pan American Health Organization outlined a program on healthy eating and active living (30), and the Disease Control Priorities Project published a framework for improving diet and lifestyle in developing countries (7).

As Ecuador's government, industry, and academia consider large coordinated interventions, it may be worth keeping in mind three characteristics of Ecuador's economy, geography, and population that are unique among South American developing countries and that may shape future interventions:

1. Ecuador has close ties to the United States (U.S.), as its gross domestic product is buoyed by oil sales to the U.S. and the government has adopted the U.S. dollar as its own currency (31, 32): for this reason, and as suggested by reports of market globalization and the nutrition transition in other countries $(8,33,34)$, Ecuador may be especially sensitive to U.S. economic, industry, and cultural influences.

2. Ecuador's landscape includes not only increasingly populated cities and less-populated, poorly diversified farmlands (32) but also the Andes mountains, Amazonian rainforest, Pacific coasts, and Galapagos islands: such a varied landscape may not permit a uniform intervention program because, as recently suggested by studies of the varied landscape of the U.S. (35), regional road density and climate patterns significantly influence exercise and physical activity.

3. With a population of only 13 million, Ecuador is the most densely settled country in South America (36); as such, and as suggested by the successes of other developing countries (7), public health efforts in Ecuador may benefit from mass media campaigns.

In light of these considerations, an intervention that, for example, calls for negotiations with transnational food corporations and simultaneously runs a population-wide campaign encouraging citizens to participate in local health-promoting activities may be effective. Tailored clinical trials 
will likely be needed to assess intervention efficacy. Meanwhile, census initiatives and further epidemiologic studies of the nutrition transition and overweight and obesity patterns will help to monitor local, regional, and national trends.

Acknowledgments. I would like to thank Manuel Baldeon, MD, PhD; David Chiriboga, MD; and Wilma Freire, $\mathrm{PhD}$, for their invaluable discussions before the preparation of this manuscript.

\section{SINOPSIS}

\section{Nuevos patrones de sobrepeso y obesidad en Ecuador}

Estudios epidemiológicos recientes han demostrado una elevada prevalencia de sobrepeso y obesidad en niños y adultos de Ecuador. Esto afecta a más de la mitad de la población, especialmente a las mujeres. También se ha observado una alta tasa de personas con síndrome metabólico, una enfermedad asociada con el exceso de peso que incrementa el riesgo de enfermedad cardiovascular.

Esos datos indican que en Ecuador está en marcha una transición nutricional -la sustitución de dietas bajas en calorías principalmente de origen vegetal por dietas ricas en calorías con más componentes de origen animal-, en la que las dietas urbanas se componen primordialmente de grasa, azúcar y cereales refinados. Esta dieta puede explicar en parte la alta prevalencia encontrada de sobrepeso y obesidad.

Las políticas internacionales que intensifican el comercio exterior y extienden el alcance de las corporaciones transnacionales de alimentos facilitan esta transición nutricional al llevar nuevos productos alimenticios a los mercados en desarrollo. Los cambios en el crecimiento de la población, la estructura por edades y la distribución de los ingresos, así como el aumento del grado de urbanización, también contribuyen a esta transición al crear grandes plazas centralizadas de consumidores.

Al diseñar programas de intervención en Ecuador se deben tener en cuenta tres características de su población, economía y geografía: 1) Ecuador mantiene estrechos lazos con los Estados Unidos de América y puede ser especialmente sensible a la influencia económica, industrial y cultural de ese país; 2) la variada geografía ecuatoriana puede impedir la aplicación de programas uniformes, ya que las diferencias regionales en la densidad de carreteras y los patrones climáticos influyen en la práctica de ejercicios y la actividad física; y 3) Ecuador es el país más densamente poblado de América del Sur. Por consiguiente, y tomando en cuenta los éxitos en este campo en otros países en desarrollo, los esfuerzos en salud pública en Ecuador se pueden ver beneficiados por campañas en los medios masivos de comunicación.

Palabras clave: sobrepeso, obesidad, Ecuador.

\section{REFERENCES}

1. Popkin BM. The nutrition transition and its health implications in lower-income countries. Public Health Nutr. 1998;1(1): 5-21.

2. Popkin BM, Gordon-Larsen P. The nutrition transition: worldwide obesity dynamics and their determinants. Int $\mathrm{J}$ Obes. 2004;28:S2-9.

3. Popkin BM. The nutrition transition: an overview of world patterns of change. Nutr Rev. 2004;62(7):S140-3.

4. Monteiro CA, Conde WL, Lu B, Popkin $\mathrm{BM}$. Obesity and inequities in health in the developing world. Int J Obes. 2004; 28:1181-6.

5. Global Infobase Online. Geneva: WHO; 2003. Available from: http://www. who.int/infobase/reportviewer.aspx? rptcode $=$ ALL\&uncode $=218 \& \mathrm{dm}=16 \&$ surveycode $=101704 a 1$. Accessed 6 July 2007.

6. Food and Agriculture Organization of the United Nations. Statistical yearbook: country profile: Ecuador. Rome: FAO; 2004. Available from: http://www.fao. org/es/ess/yearbook/vol_1_2/pdf/ Ecuador.pdf. Accessed 4 July 2007.

7. Willett WC, Koplan JP, Nugent R, Dusenbury C, Puska P, Gaziano T. Pre- vention of chronic disease by means of diet and lifestyle changes. In: Jamison D, Breman J, Measham A, Alleyne G, Claeson M, Evans DB, et al., eds. Disease control priorities in developing countries. 2nd ed. Washington, DC: The World Bank Group; 2006. Pp. 833-51.

8. Hawkes C. Uneven dietary development: linking the policies and processes of globalization with the nutrition transition, obesity, and diet-related chronic diseases. Global Health. 2006;2(4).

9. Global Infobase Online. Geneva: WHO; 2005. Available from: http://www.who. int/infobase / compare.aspx? $\mathrm{dm}=5 \&$ countries $=218 \&$ year $=2005 \&$ sf $1=$ cd .0704 $\&$ sex=all\&agegroup $=15-100$. Accessed 5 February 2008.

10. Instituto Nacional de Estadistica y Censos. Quito, Republica del Ecuador: 2008. Available from: http://www.inec.gov.ec/ default.asp. Accessed 13 February 2008.

11. Sobal J, Stunkard A. Socioeconomic status and obesity: a review of the literature. Psychol Bull. 1989;105(2):260-75.

12. Martorell R, Kettel Khan L, Hughes ML, Grummer-Strawn LM. Obesity in Latin American women and children. J Nutr. 1998;128:1464-73.
13. Lopez-Jaramillo P, Lopez de Garcia A, Prevot C, Felix C, Sosa C, Romero R, et al. Effect of social class and nutrient intake on height and plasma insulin-like growth factor in Andean Equadorian children. Eur J Clin Nutr. 1992;46(2):137-42.

14. Larrea $C$, Freire W. Social inequality and child malnutrition in four Andean countries. Rev Panam Salud Publica. 2002; 11(5-6):356-64.

15. Macdonal B, Johns T, Gray-Donald K, Receveur O. Ecuadorian Andean women's nutrition varies with age and socioeconomic status. Food Nutr Bull. 2004;25(3):239-47.

16. Aguilar D, Alarcon E, Guerron A, Lopez $P$, Mejia S, Riofrio L, et al. El sobrepeso y la obesidad en escolares ecuatorianos de 8 años de edad del area urbana. Boletin Informativo OPS/OMS (Representacion Ecuador). 2003;11.

17. Burbano JC, Fornasini M, Acosta M. Prevalence of and risk factors for overweight among school girls 12 to 19 years old in a semi-urban region of Ecuador. Rev Panam Salud Publica. 2003;13(5): 277-84.

18. Caicedo R, Moreno M, Narvaez M, Naranjo E. Estado nutricional y meta- 
bolico en escolares de Quito. Facultad de Medicina, Universidad Central; 2005. Accessed through Manuel Baldeon.

19. Waters WF. Globalization and local response to epidemiological overlap in 21st century Ecuador. Global Health 2006;2(8).

20. Filozof C, Gonzalez C, Sereday M, Mazza C, Braguinsky J. Obesity prevalence and trends in Latin-American countries. Obes Rev. 2001;2(2):99-106.

21. Peña $M$, Bacallao J. Obesity among the poor: an emerging problem in Latin America and the Caribbean. Report No. 576. Washington, DC: Pan American Health Organization; 2000.

22. Groeneveld IF, Solomons NW, Doak CM. Nutritional status of urban schoolchildren of high and low socioeconomic status in Quetzaltenango, Guatemala. Rev Panam Salud Publica. 2007;22(3): 169-77.

23. World Health Organization. Overweight and obesity. In: World Health Organization, ed. Global and regional burden of disease attribution to selected risk factors. 1st ed. Geneva: WHO; 2004.

24. Rodriguez T, Malvezzi M, Bosetti C, Levi F, Negri E, La Vecchia C. Trends in mortality from coronary heart and cere- brovascular diseases in the Americas: 1970-2000. Heart. 2002;92:453-60.

25. Bosetti C, Malvezzi M, Chatenoud L, Levi F, Negri E, La Vecchia C. Trends in cancer mortality in the Americas: 1970 2000. Ann Oncol. 2005;16(3):489-511.

26. Mortality Database. Geneva: WHO; 2000. Available from: http://www. who.int/whosis/database/mort/table1. cfm. Accessed 1 July 2007.

27. Hidalgo LA, Chedraui PA, Morocho N, Alvarado M, Chavez D, Huc A. The metabolic syndrome among postmenopausal women in Ecuador. Gynecol Endocrinol. 2006;22(8):447-54.

28. Jacoby E. The obesity epidemic in the Americas: making the healthy choices the easiest choices. Rev Panam Salud Publica. 2004;15(4):278-84.

29. World Health Organization. Obesity and overweight. Geneva: WHO; 2006. Available from: http://www.who.int/ mediacentre/factsheets/fs311/en/ index.html. Accessed 24 June 2007.

30. Pan American Health Organization. Regional program on healthy eating and active living. Washington, DC: $\mathrm{PAHO}$ 2006. Available from: http://www.paho. org/english/ad/dpc/nc/heal-programpage.htm. Accessed 26 December 2006.
31. U.S. Department of Energy. Crude oil and total petroleum imports: top 15 countries. Washington, DC: United States Department of Energy, Energy Information Administration; 2008. Available from: http://www.eia.doe.gov/pub/oil_gas/ petroleum/data_publications/company_ level_imports/current/import.html.

32. The World Bank. Ecuador country brief: development progress. Washington, DC: The World Bank; 2006. Available from: www.worldbank.org. Accessed 3 February 2007.

33. Hawkes $\mathrm{C}$. The role of foreign direct investment in the nutrition transition. Public Health Nutr. 2005;8(4):357-65.

34. Hossain P, Kawar B, El Nahas M. Obesity and diabetes in the developing world-a growing challenge. $\mathrm{N}$ Engl J Med. 2007;356(3):213-5.

35. Lin G, Spann S, Hyman D, Pavlik V. Climate amenity and BMI. Obesity (Silver Spring). 2007;15(8):2120-7.

36. United Nations Populations Division. World population prospects: the 2006 revision population database. New York: United Nations Population Division; 2006. Available from: http:// esa.un.org/unpp/. Accessed 13 February 2008.

\section{Nutrition and an Active Life: From Knowledge to Action}

Nutrition and an Active Life: From Knowledge to Action is an anthology by leading public health experts from PAHO and the international development community. The book's selections focus on how research in nutrition and the promotion of active lifestyles can provide vital input for the creation of public policy and planning and for the design, implementation, monitoring, and evaluation of programs.

This publication is an important contribution that should be of particular interest to practitioners, researchers, and decisionmakers in the fields of health promotion, community education, nutrition, maternal and child health, physical activity, policy development in public health and urban planning, and other related areas.

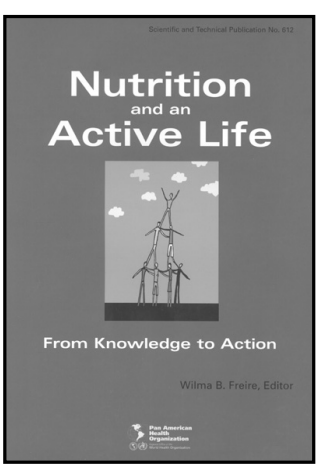

2005, pp., 260

ISBN: 9275116121

US\$ 20.00 in Latin America

and the Caribbean/

US\$ 30.00 elsewhere

Order code: SP 612 